\title{
FURTHER POTENTIAL SAVINGS ATTRIBUTABLE TO MAXIMUM GENERIC substitution of antidepressants in South Africa: A retrospective ANALYSIS OF MEDICAL CLAIMS
}

Authors:

Elmarie van der Westhuizen ${ }^{1}$ Johanita R. Burger ${ }^{1}$

Martie S. Lubbe ${ }^{1}$

Jan H.P. Serfontein ${ }^{1}$

\section{Affiliations: \\ ${ }^{1}$ School of Pharmacy, \\ North-West University, \\ Potchefstroom campus, \\ South Africa}

Correspondence to:
Johanita Burger

email:

johanita.burger@nwu.ac.za

Postal address:

School of Pharmacy, NorthWest University, Private Bag X6001, Potchefstroom 2520, South Africa

\section{Keywords:}

cost savings; drug utilisation review; generic equivalents; innovators; Statistical

Analysis System ${ }^{\circledR}$ program

Dates:

Received: 11 Nov. 2009

Accepted: 04 June 2010

Published: 24 Nov. 2010

How to cite this article:

Van der Westhuizen,

E., Burger, J.R., Lubbe,

M.S., Serfontein, J.H.P.

'Further potential savings attributable to maximum generic substitution of antidepressants in South Africa: A retrospective analysis of medical claims', Health SA Gesondheid 15(1), Art. \#520, 5 pages. DOI: 10.4102/hsag.v15i1.520

This article is available at:

http:/ /www.hsag.co.za

(C) 2010. The Authors.

Licensee: OpenJournals Publishing. This work is licensed under the Creative Commons Attribution License.

\section{ABSTRACT}

The main objective of the study was to calculate potential cost savings that could have been generated by maximum generic substitution of antidepressants within the private health care sector of South Africa from 2004 to 2006. Data on computerised medicine claims of patients receiving one or more antidepressants during three consecutive years (i.e. 2004, 2005 and 2006) were elicited from a South African pharmaceutical benefit management company. The total study population consisted of 292 071 items $(N=5982869)$ on 273673 prescriptions $(N=5213765)$ at a total cost of R56 183697.91 ( $N=\mathrm{R} 1346210$ 929.00). A quantitative, retrospective drug utilisation review was conducted, and data were analysed using the Statistical Analysis System ${ }^{\circledR}$ programme. Potential cost savings were computed for criteria-eligible substances in the study population. Generic medicine constituted $58.7 \%(N=292071)$ of all antidepressants claimed, at a total cost of $28.2 \%(N=\mathrm{R} 1346210929.00)$ of all incurred costs. With total substitution of the average price of all criteria-eligible innovators, a potential saving of $9.3 \%(N=R 56183697.91)$ of the actual antidepressant cost over the study period was calculated. In developing countries with limited health care resources, generic medicines can be cost-saving treatment alternatives.

\section{OPSOMMING}

Die hoofmikpunt van hierdie studie was om die potensiële kostebesparing te bereken wat deur maksimale generiese vervanging van antidepressante in die Suid-Afrikaanse private gesondheidsorgsektor tussen 2004 en 2006 teweeggebring sou kon word. Data oor gerekenariseerde eise vir medisyne van pasiënte wat een of meer antidepressante gedurende die studietydperk ontvang het (d.i. 2004, 2005 en 2006) is van 'n Suid-Afrikaanse maatskappy wat farmaseutiese voordele bestuur, verkry. Die totale studiepopulasie het bestaan uit 292071 items ( $N=5982869$ ) van 273673 voorskrifte $(N=5213765)$ teen 'n totale koste van R56 183697.91 ( $N=$ R1 346210929.00$)$. 'n Kwantitatiewe, retrospektiewe medisyneverbruiksontleding is gedoen en data is geanaliseer deur van die Statistical Analysis System $®$-pakket gebruik te maak. Potensiële kostebesparings is vir middels in die studiepopulasie wat aan die kriteria voldoen het, bereken. Generiese produkte het $58.7 \%(N=292071)$ van alle produkte wat voorgeskryf is, uitgemaak, teen 'n totale koste van $28.2 \%(N$ $=\mathrm{R} 1346210929.00$ ). Indien die gemiddelde prys van alle middels wat aan die kriteria vir vervanging voldoen het, met die prys vir generiese middels vervang word, is 'n potensiële besparing van $9.3 \%$ $(N=$ R56 183 697.91) van die werklike koste vir antidepressante gedurende die studietydperk moontlik. Generiese middels kan in ontwikkelende lande met beperkte gesondheidsorg-hulpbronne kostebesparende alternatiewe wees.

\section{INTRODUCTION}

\section{Background}

In South Africa, $13 \%$ of the population live in 'first world' conditions, whilst nearly half of the population of approximately 48 million people (gross domestic product [GDP] percentage $=8 \%$ ) live in developingcountry conditions (World Bank 2009). The health care sector is divided between two entities: a public sector that provides health care services to approximately $86 \%$ of the population versus a private sector that serves the remainder of the population (i.e. 6.7 million people) (Leon \& Mabope 2005:33; Pick 2008:7). In 2005-2006, South Africa spent approximately 8.7\% (approximately R135 billion) of its GDP on health sector financing (World Health Organization 2008:90). Of this, 56\% went through the medical aid industry that serves the private health care sector (Blecher \& Harrison 2006:32; Department of Health 2007). The private health care sector thus provides services to a minority of the South African population, whilst responsible for more than half of the country's annual health care expenditure.

In contrast to the public health sector (financed through nationally collected general tax and other revenues) where expenditure has been relatively stagnant in real per capita terms over the last decade, expenditure in the private sector (financed mainly by medical schemes and health insurance) has continued to increase on an annual basis from the 1980s, at rates beyond those of inflation (McLeod \& Ramjee 2007:50; McIntyre \& Thiede 2007:41). One of the primary cost drivers of medical expenditure in the private health care sector of South Africa has been medicines, accounting for $18.3 \%$ of the total spent by medical schemes. Other main contributors to medical scheme costs were hospitals (excluding specialists and general practitioners) and specialists, accounting for $29.7 \%$ and $18 \%$ of expenditure respectively (Masobe 2008:9). Antihypertensives, hypolipidaemic agents and antidepressants were the three therapeutic groups contributing most to medicine expenditure in 2004, 2005 and 2006 (Bester, Brews \& Hammann 2006:9; Bester \& Hammann 2007:9; Bester \& Hammann 2008:10).

A number of initiatives (strategic and policy developments) have been encouraged to change the face of the medical schemes industry in South Africa significantly, amongst others, the establishment of prescribed minimum benefits (PMBs), formularies, a reference-based pricing system and mandatory generic substitution.

Most countries in the world today support the use of generic drugs and over $60 \%$ of them report having some guideline for generic substitution in private pharmacies (Quick et al. 2002:913). In current form, 
the generic substitution provision in the Medicines and Related Substance Control Act 101 of 1965 of South Africa as amended in 1997 (South Africa Government 1997:42; implemented 02 May 2003) compels pharmacists to offer patients a generic substitute for any medicine prescribed, unless the prescriber explicitly stated that the medicine should not be substituted or the price of the generic is higher than that of the innovator product. The final choice, however, rests with the patient.

In general, generic medicines are considerably less expensive than innovator medicines and their endorsement can lead to substantial savings in costs (Frank 2007:1993). Recent research confirmed the cost-saving value of generic substitution in countries such as The Netherlands (Boersma et al. 2005:191), Australia (McManus et al. 2001:295), British Columbia (Morgan, Agnew \& Barer 2004:299), Sweden (Andersson et al. 2005:341), Belgium (Simoens et al. 2005:755), Spain (Ubeda et al. 2007:181), the United States of America (Haas et al. 2005:894), Ireland (Tilson et al. 2003:176) and Finland (Global Insight Inc. 2007) Some research has been conducted on the influence of generic substitution on the cost of medicine in South Africa. In 1990, Boyce and Bartlett (1990:147) showed that cost savings from generic prescribing and generic substitution can, depending on the item involved, range from $9.9 \%$ to $59.7 \%$ (mean $41.1 \%$ ). Later in 1996, Karim et al. (1996:198) reported that generic prescribing and substitution have the potential to reduce medicine costs by a further average of nearly $10 \%$ if practised to maximum capacity in South Africa. Bester and Hammann (2008:6) estimated that only approximately $45 \%$ of innovator products in the South African market are currently substituted for less expensive generics, compared to 54\% in the USA (Levinson 2006:9).

\section{Study objectives}

In developing countries with limited health care budgets, such as South Africa, generic medicines can be cost-saving treatment alternatives. Health care professionals, third-party payers and patients all have fundamental roles to play in order to encourage greater use of generics. Medicine expenditure can thereby be reduced and access to scarce resources increased, in order to meet the pressing health care needs within South Africa. In light of this, the present study has the following objectives, (1) To determine the extent of the use of generic medicines, specifically antidepressants, in the private health care sector of South Africa during the period 2004-2006 and (2) to illustrate further potential cost savings that could have been generated by practising generic prescribing and/or substitution to maximum capacity in the private health care sector of South Africa during the period 2004-2006. Antidepressant prescribing patterns are used as an example.

This paper is presented in four sections. The first deals with the status of generic substitution in South Africa and some example countries around the world. The second section deals with the research approach and method followed during the empirical investigation of the study. An outline of results follows in the third section, and a discussion of the results, implications of the findings, and limitations of the study appears in the fourth section of the paper. We conclude with some suggestions for future research.

\section{RESEARCH METHOD AND DESIGN}

\section{Research approach}

A quantitative, non-experimental approach was applied using a basic, descriptive design to analyse secondary prescription claims data.

\section{Research method}

\section{Research population and sampling}

Data were elicited from a South African pharmaceutical benefit management (PBM) company that manages the benefits of medical schemes and insurance companies in South Africa by applying a real-time auditing process to claims from pharmacies and other service providers. In 2004, this PBM performed services for 50\% of South Africa's 133 medical aid schemes and for $68(N=131)$ and $35(N=124)$ individual medical aid schemes respectively in 2005 and 2006.

The dataset for 2004 consisted of a total number of 2595242 prescriptions, for a total number of 5305846 dispensed medicine items, at a total cost of R661 221000.00 . The 2005 dataset contained 1621736 prescriptions and 3606992 dispensed medicine items at a total cost of R405 829 097.00, whereas the 2006 dataset consisted of 996787 prescriptions and 2370572 dispensed medicine items at a total cost of R279 160832.00 .

The study population (see Table 1) consisted of all patients who had at least one prescription for an antidepressant drug filled during a 36-month period (01 January 2004 to 31 December 2006).

\section{Research procedure}

A quantitative, retrospective drug utilisation study was performed to explore prescribing patterns for antidepressants.

Antidepressant medicines were identified on the basis of a list of medications used by South African health care professionals (Monthly Index of Medical Specialties, also known as MIMS Snyman 2006) and assigned to one of seven classes: tricyclics, non-tricyclic, mono-amine oxidase inhibitors, selective serotonin reuptake inhibitors, serotonin and noradrenaline reuptake inhibitors, lithium and 'others' (i.e. bupropion, flupenthixol, fluphenazine, mirtazapine, reboxetine, sulpiride, trazodone and perphenazine/nortriptyline combination). Antidepressant medicines were classified as either innovator or generic.

Innovator medicine was defined as original research products (that is, assigned a patent on the chemical formulation or manufacturing process) for which there may (or may not) have been a generic equivalent(s) available during the study period. Generic equivalent medicine was defined as products approved by and registered with the Medicine Control Council (2003) of South Africa and that contain the same substance as the innovator, available in the same pharmaceutical form (capsules and tablets were considered alike) and strength and/ or concentration as the innovator medicine.

An assessment of innovator and generic antidepressant prescribing included measures of the frequency of the claims and total medicine treatment cost.

\section{Data collection and statistical analysis}

All the prescription records of patients who had at least one prescription for an antidepressant filled over the study period were used for analysis.

Basic descriptive statistics, that is, frequencies, the arithmetic mean (average) and standard deviations, and inferential statistics (effect sizes; Cohen 1988:3), were used to characterise the study sample and were calculated using the Statistical Analysis System ${ }^{\circledast}$ SAS for Windows $9.1^{\circledast}$ program (SAS 2005).

Generic substitution percentage rates, defined as the number of generic claims divided by the total number of claims for a specific active substance (generic plus innovator), were used to indicate 'optimal' substitution rates for individual active substances and therapeutic classes.

Potential cost savings (defined as the collective amount that could be saved annually by substituting the average price of innovator active substances for that of generic equivalent(s)) were calculated using the following formula:

Cost saving $=\left(\right.$ Average $\operatorname{cost}_{\mathrm{I}}-$ Average $\left.\operatorname{cost}_{\mathrm{G}}\right) \mathrm{n}_{\mathrm{I}^{\prime}}$

[Eqn 1]

where,

- Average cost $t_{1}=$ the average cost of the innovator product

- Average $\operatorname{cost}_{\mathrm{G}}=$ the average cost of the generic equivalent(s)

- $\mathrm{n}_{\mathrm{I}}=$ number of innovator medicines claimed during the specific study period. 
In cases where the innovator was less expensive than the available generic equivalent(s) or where there was no generic equivalent(s) available for the specific innovator during the specific year of study, the specific substance was excluded from the analysis.

\section{RESULTS}

A description of the study population for all three study periods is indicated in Table 1.

Antidepressant prescriptions comprised 5.3\% of prescriptions claimed via the PBM throughout the three study years $(N=5213$ $765)$. The total number of antidepressants (items) prescribed (i.e. the study population) represented $2.6 \%$ of all items prescribed over the three-year study period $(N=11283410)$, at a total claimed cost of $4.2 \%(N=\mathrm{R} 1346210929.00)$ of the total cost of claims (see Table 1). The number of items claimed progressively decreased over the study period from $3 \%$ in 2004 to $2.4 \%$ in 2005 and $2 \%$ in 2006; costs likewise decreased from $4.9 \%$ in 2004 to $3.8 \%$ in 2005 , to $3.1 \%$ in 2006 . An average of $1.1 \pm 0.26$ antidepressants (items) were claimed per prescription at an average cost of R192.36 \pm R187.59 per item.

Generic items represented $58.7 \% \quad(N=157810)$ of the antidepressants claimed during 2004, 56.1\% $(N=86521)$ claimed during 2005 and 63.3\% $(N=47740)$ claimed during 2006. Associated total item costs represented $31.5 \%(N=\mathrm{R} 32323$ $356.77)$ during 2004, 22.3\% ( $N=$ R15 245709.85$)$ during 2005 and $26.1 \%(N=\mathrm{R} 8614631.29)$ during 2006. Approximately 59\% $(N$ = 292 071) of all antidepressants claimed during the three-year study period were thus generic products, at a total cost of R15 834 316.30 or $28.2 \%$ of costs incurred. Innovator items subsequently represented the remaining $41.3 \%$ of the claimed items at $71.8 \%$ of total incurred costs. The average cost of innovators over the three-year study period was R334.21 \pm R203.42 compared to the $\mathrm{R} 92.41 \pm \mathrm{R} 81.63$ of generic items $(d=1.2)$.

\section{Potential cost savings}

The calculated potential cost savings attributable to generic equivalent substitution are set out in Table 2, see online supplementum.

Substitution rates equal to or more than $80 \%$ were found in certain pharmacological classes during the study period, that is, the tricyclic antidepressants (specifically amitriptyline [10 mg and $25 \mathrm{mg}$ ], dothiepin $75 \mathrm{mg}$ and trimipramine $50 \mathrm{mg}$ during 2004-2005 and dothiepin $25 \mathrm{mg}$ during 2006) and the selective mono-amine oxidase inhibitors (including moclobemide 300 mg during 2005 and moclobemide $150 \mathrm{mg}$ during 2004-2006). Individual substances with substitution rates of more than $79 \%$ also included citalopram $20 \mathrm{mg}$ (2005-2006), fluoxetine $20 \mathrm{mg}$ (2004-2006), fluoxetine $40 \mathrm{mg}$ (2005) and sulpiride $50 \mathrm{mg}$ (2005-
2006). In contrast, the pharmacological classes of non-tricyclic antidepressants, non-selective mono-amine oxidase inhibitors, lithium and 'others' (excluding sulpiride $50 \mathrm{mg}$ ) had no generic equivalent available during the study period.

With total substitution of the average price of all innovators that have generic equivalent(s) available on the datasets and where the generic(s) was less expensive than the innovator product, a saving of R1 984176.62 , or $6.12 \%$ of the actual antidepressant cost for 2004, was found. Total savings of R1 835025.20 or 12.04\% during 2005 and R1 407 463.70, or 16.34\% during 2006, were also calculated. In total, a maximum saving of $9.30 \%(N=$ R56 183 697.91) of the actual antidepressant cost on the research database for the three-year study period was possible.

\section{ETHICAL CONSIDERATIONS}

Unique encrypted numbers were used to prohibit the identification of the patient, thus maintaining anonymity. Permission to conduct the study was granted by the PBM Company and the North-West University Research Committee.

\section{TRUSTWORTHINESS}

The data were obtained directly from the medicine claims database and no direct manipulation of the data was done by the researcher. Research was conducted from the perspective that all data obtained from the medicine claims database were reliable and valid. The database, however, was verified by testing for outliers, as well as performing random data checks.

Since the data of only one PBM company were used in this study, no cost or prevalence comparisons could be made. External validity was also limited, implying that the results of the study can be generalised to the specific database and study population only.

\section{DISCUSSION}

This study set out to determine the extent of the use of generic medicines as alternatives for cost-driving medicine in the private health care sector of South Africa. Secondly, the intention was to illustrate the potential cost savings that can be generated by implementing generic prescribing substitution to maximum capacity in this sector. Generic medicines can be cost-saving treatment alternatives in a developing country with a limited health care budget, such as South Africa. The results of this study highlight the role of generics in the reduction of medicine expenditure in a section of the private health care sector of South Africa. There were two key findings in line with the objectives of this study.

Firstly, this study shows that generic substitution rates in the study population increased by almost $5 \%$ during the

TABLE 1

Description of antidepressant population

\begin{tabular}{|c|c|c|c|c|c|c|}
\hline \multirow[t]{2}{*}{ Variable } & \multicolumn{2}{|c|}{2004} & \multicolumn{2}{|c|}{2005} & \multicolumn{2}{|c|}{2006} \\
\hline & $\mathbf{N}$ & $\%$ & $\mathbf{N}$ & $\%$ & $\mathbf{N}$ & $\%$ \\
\hline Number of prescriptions & 146905 & 5.7 & 81830 & 5.1 & 44938 & 4.5 \\
\hline Number of dispensed medicine items & 157810 & 3.0 & 86521 & 2.4 & 47740 & 2.0 \\
\hline Number of items per prescription & $1.07 \pm 0.28$ & & $1.06 \pm 0.24$ & & $1.06 \pm 0.25$ & \\
\hline Total item cost & R 32323356.77 & 4.9 & R 15245709.85 & 3.8 & R 8614631.29 & 3.1 \\
\hline Average cost per item (mean \pm s.d.) & $\mathrm{R} 204.82 \pm \mathrm{R} 186.14$ & & $\mathrm{R} 176.21 \pm \mathrm{R} 178.81$ & & $\mathrm{R} 180.45 \pm \mathrm{R} 204.20$ & \\
\hline Number of generic items & 92581 & 1.7 & 48540 & 1.4 & 30220 & 1.3 \\
\hline Total generic item cost & R 10189602.24 & 2.5 & R 3394250.99 & 0.8 & R 2250463.07 & 0.8 \\
\hline Average cost per generic item (mean \pm s.d.) & $\mathrm{R} 110.06 \pm \mathrm{R} 89.23$ & & $\mathrm{R} 69.93 \pm \mathrm{R} 60.14$ & & $\mathrm{R} 74.47 \pm \mathrm{R} 74.11$ & \\
\hline Number of innovator items & 65229 & 1.2 & 37981 & 1.1 & 17520 & 0.7 \\
\hline Total innovator item cost & R 22133754.53 & 3.4 & R 11851458.86 & 2.9 & R 6364168.22 & 2.3 \\
\hline Average cost per innovator item (mean \pm s.d.) & $R 339.32 \pm R 204.14$ & & $R 312.04 \pm R 87.96$ & & $R 363.25 \pm R 226.61$ & \\
\hline
\end{tabular}

s.d., standard deviation. 
study period, from $58.7 \%(N=157810)$ of the antidepressants claimed during 2004 to $63.3 \%(N=47740)$ during 2006. This increase was probably due to the legislation (more stringent reference pricing and mandatory generic substitution already proceeding at pharmacy level in South Africa) and greater acceptance of generic medicines by prescribers and pharmacists (Deroukakis 2007:63). Managed health care initiatives such as the introduction of formularies that promote the utilisation of generic medicines for the management of disease conditions in South Africa from external sources (i.e. third-party payers) may also have encouraged the use of generics.

Analysis of the generic substitution percentage rates furthermore showed that generic medicines were mostly claimed for certain individual substances and pharmacological classes of antidepressants during the study period. The nontricyclic antidepressants, non-selective mono-amine oxidase inhibitors, lithium and 'others' (with the exception of sulpiride $50 \mathrm{mg}$ ), however, had no generic equivalent available on the datasets during the study period. Claims for the nontricyclic antidepressants, non-selective mono-amine oxidase inhibitors and lithium together, however, formed only $3.34 \%$ of antidepressant claims over the study period, whereas 'others' represented $9.7 \%(N=292071)$. From a management perspective, antidepressants classified as 'others' therefore seemed to be the most favourable for the marketing and/or development of generic equivalents due to their non-availability. Many of the agents in this group were, however, still under patent protection during the study period.

The total number of antidepressant claims on the database decreased progressively over the study period. The associated average cost per item seemed to decrease in 2005, after which an increase was observed in 2006. The decrease in the total number of claims from the beginning to the end of the study period may be ascribed to the decrease in medical scheme members and/or the decrease in the number of medical schemes administrated by the PBM Company. The decrease in the average cost of antidepressant items in 2005 (and subsequent increase in 2006) was most likely a result of the reference-based pricing system implemented on 1 September 2004. The regulations relating to this transparent pricing system for medicines and scheduled substances (Department of Health 2004:7) allowed for a dispensing fee of $26 \%$ of the single exit price of medicines with a cap of R26.00 for all Schedule 3-6 medicines, whilst increases in medicine prices were capped at $5.2 \%$ (for a period of approximately three years). The South African Constitutional Court, however, found this original dispensing fee for pharmacists inappropriate in September 2005. More than a year elapsed without any control over dispensing fees before a new fee was finally proposed in December 2006 (Taylor 2007:128).

Secondly, this study showed that by practising generic substitution and/or dispensing to maximum capacity in our study population, a saving of $9.3 \%(N=R 56183697.91)$ of the actual antidepressant cost on the research database, for the three-year study period, was possible. This translates to a $0.4 \%$ saving for the total database ( $N=\mathrm{R} 1346210929.00)$ over the study period. Total substitution would, however, be unlikely due to some prescribers and patients preferring the innovator or brand-name product in $40 \%-60 \%$ of cases (Banahan \& Kolassa 1997:2081; Gaither et al. 2001:734; Mott \& Cline 2002:670). By substituting only $40 \%$ of available innovator antidepressants on the database with generic equivalents, a cost saving of more than R2 million or $0.16 \%(N=R 1346210929.00)$ of the PBM company's expenditure over the three-year study period would still have been possible. Steyn (2005) determined that in 2004, generic substitution could have saved up to $7.8 \%(N=\mathrm{R} 29734$ 655.19) of total medical claim costs of antidiabetic medicine. More recently, Bloem (2009) illustrated potential savings of up to $1.63 \%(N=\mathrm{R} 106943348.53)$ in 2005 and $1.3 \%(N=\mathrm{R} 117$ 862631.87 ) in 2006 by substituting hypolipidaemic drugs for less expensive generics on a large medical claims database. Whilst these savings appear modest, national savings would be substantial with wider implementation. The substitution of cost-driving medicine with less expensive generic equivalents, therefore, has the potential to reduce medication, and thus health care costs, significantly in the private health care sector of South Africa.

Other noteworthy findings of this study were that the average price for generic antidepressants decreased by 32\% from 2004 to 2006, whilst the average price of innovator antidepressants increased by $7.1 \%$ during the same time. According to Frank and Salkever (1997:78), intense generic competition may cause a decrease in the price of generic pharmaceuticals and an increase in the price of brand-name pharmaceuticals. Our analysis showed that a relatively high number of new antidepressants entered the South African market during 2005-2006 (i.e. 25 new generic products vs. three new innovator products; Van der Westhuizen, 2007). The impact of new chemical entities with blockbuster potential (i.e. Cymbalta ${ }^{\mathrm{TM}}$ and Cipralex ${ }^{\mathrm{TM}}$; Bester \& Hammann 2008:13) should, however, not be excluded as a reason for price increases amongst innovator antidepressants as high premiums are often asked for these medicines.

\section{LIMITATIONS OF THE STUDY}

Certain limitations of the study were identified. Firstly, the impact of generic prescribing and/or substitution of antidepressants on health care cost in the private sector could not be compared to that of the public health care sector in South Africa, as the procurement of all medicine in the public sector institutions or state-associated treatment facilities in South Africa occurs through a tender system based on national and international tender principles (DOH 1996). The private health care sector operates according to the single exit price (SEP) system. Tender time periods in the public sector furthermore differ for the different categories of medicine in South Africa and are thus usually not comparable with price systems in the private sector. Secondly, the use of the database employed in this study was justified by its being electronically available and accessible. However, claims not submitted through the PBM company (such as patients who paid cash for their medication for various reasons, e.g. exceeded scheme benefits and/or because they were not members of a medical scheme) were excluded from the study. Again, usage and/or prescribing patterns were difficult to compare to the public health care sector in South Africa, as this sector does not have a medicine and/or resource usage database that is electronically available at present. Finally, data for the analysis were also obtained from the database of one PBM company only, therefore limiting external validity.

\section{CONCLUSION AND RECOMMENDATIONS}

The results of this study suggest that there is potential for further maximum cost savings due to generic substitution in the private health care sector. Patients and prescribers should be made aware of the benefits of generic prescribing in terms of possible cost savings. Third-party payers within the private health care sector of South Africa might also need to focus on the use of generics in the compilation of medicine formularies. Further research is needed on other cost-driving medicines in the private health care sector in order to determine the potential savings at national level.

\section{ACKNOWLEDGEMENTS}

The study has been partly supported by the National Research Foundation (NRF). The authors wish to thank the South African PBM Company that provided this data. The interpretation of the results does not necessarily reflect the views of the NRF or the PBM Company. We are also grateful to Ms A. Bekker for assisting in data analysis and Ms M. Terblanche for proofreading the article in preparation for review.

\section{REFERENCES}

Andersson, K., Sonesson, C., Petzold, M., Carlsten, A. \& 
Lönnroth, K., 2005, 'What are the obstacles to generic substitution? An assessment of the behaviour of prescribers, patients and pharmacies during the first year of generic substitution in Sweden', Pharmacoepidemiology and Drug Safety 14(5), 341-348.

Banahan, B.F. \& Kolassa, E.M., 1997, 'A physician survey on generic drugs and substitution of critical dose medications', Archives of Internal Medicine 157(18), 2080-2088.

Bester, M., Brews, M. \& Hammann, E., 2006, Mediscor medicines review-2005, viewed 2 September 2006, from http://www. mediscor.net

Bester, M. \& Hammann, E., 2007, Mediscor medicines review-2006, viewed 13 August 2007, from http:/ / www.mediscor.net

Bester, M. \& Hammann, E., 2008, Mediscor medicines review-2007, viewed 25 August 2009, from http:/ / www.mediscor.net

Blecher, M. \& Harrison, S., 2006, 'Health care financing', in P. Ijumba \& A. Padarath (eds.), South African health review-2006, pp. 31-64, Health Systems Trust, Durban.

Bloem, J., 2009, A retrospective analysis of the usage patterns of hipolipidaemic drugs: A pharmacoeconomic approach, $\mathrm{M}$ Pharm Dissertation, Dept. of Pharmacy Practice, North-West University.

Boersma, C., Klok, R.M., Bos, J.M., Naunton, M., Van den Berg, P.B., De Jong-van den Berg, L.T.W. et al., 2005, 'Drug costs developments after patent expiry of enalapril, fluoxetine and ranitidine: A study conducted for The Netherlands', Applied Health Economics and Health Policy 4(3), 191-196.

Boyce, D. \& Bartlett, G., 1990, 'The maximum medical aid price programme: A review of the concept and of its ability to reduce expenditure on medicine', South African Pharmaceutical Journal 78, 147-151.

Cohen, J., 1988, 'Statistical power analysis for the behavioural sciences', Erlbaum, Hillsdale, New Jersey.

Department of Health, 1996, National drug policy for South Africa, Government Printer, Pretoria.

Department of Health, 2004, Regulations relating to a transparent pricing system for medicines and scheduled substances, Government Gazette No.29443, 01 December 2006.

Department of Health, 2007, Macro-analysis of the current situation in private health sector, viewed 22 October 2008, from http:/ / www.doh.gov.za/docs/presentation/indaba/macroanalysis.pdf

Deroukakis, M., 2007, 'Mandatory substitution successful', South African Pharmaceutical Journal 97, 63-64.

Frank, R.G., 2007, 'The ongoing regulation of generic drugs', The New England Journal of Medicine 357(20), 1993-1996.

Frank, R.G. \& Salkever, D.S., 1997, 'Generic entry and the pricing of pharmaceuticals', Journal of Economics $\mathcal{E}$ Management Strategy 6(1), 75-90.

Gaither, C.A., Kirking, D.M., Ascione, F.J. \& Welage, L.S., 2001, 'Consumers' views on generic medications', Journal of the American Pharmaceutical Association 41(5), 729-736.

Global Insight Inc., 2007, Generic substitution saves Finland US\$54.8 mil. in 2007, viewed 16 May 2008, from http:// www.globalinsight.com/SDA/SDADetail11882.htm

Haas, J.S., Phillips, K.A., Gerstenberger, E.P. \& Seger, A.C., 2005, 'Potential savings from substituting generic drugs for brandname drugs: Medical expenditure panel survey, 1997-2000', Annals of Internal Medicine 142(11), 891-897.

Karim, S.S.A., Pillai, G., Ziqubu Page, T.T., Cassimjee, M.H. \& Morar, M.S., 1996, 'Potential savings from prescribing and generic substitution in South Africa', Health Policy and Planning 11(2), 198-205.

Leon, N. \& Mabope, R., 2005, 'The private health sector', in P. Ijumba \& P. Barron (eds.), South African health review-2005, pp. 32-43, Health Systems Trust,Durban..

Levinson, D.R., 2006, Generic drug utilization in state Medicaid pro- grams, viewed 15 June 2008, from http: / www.oig.hhs.gov / oei/reports/oei-05-05-00360.pdf

Masobe, T.P., 2008, 'Executive summary', in Office of the Registrar of Medical Schemes, Evaluation of medical schemes' cost increases: Findings and recommendations, pp. 9-14, Council for Medical Schemes, Pretoria.

McIntyre, D. \& Thiede, M., 2007, 'Health care financing and expenditure', in S. Harrison., R. Bhana \& A. Ntuli (eds.), South African health review-2007, pp. 35-46, Health Systems Trust, Durban.

McLeod, H. \& Ramjee, S., 2007, 'Medical schemes', in S. Harrison., R. Bhana \& A. Ntuli (eds.), South African health review-2007, pp. 47-70, Health Systems Trust, Durban.

McManus, P., Birkett, D.J., Dudley, J. \& Stevens, A., 2001, 'Impact of the minimum pricing policy and introduction of brand (generic) substitution into pharmaceutical benefits scheme in Australia', Pharmacoepidemiology and Drug Safety 10(4), 295-300.

Medicines Control Council, 2003, Generic substitution, Department of Health, South Africa.

Morgan, S.G., Agnew, J.D. \& Barer, M.L., 2004, 'Seniors' prescription drug cost inflation and cost containment: Evidence from British Columbia', Health Policy 68(3), 299307

Mott, D.A. \& Cline, R.R., 2002, 'Exploring generic use behavior: The role of prescribers and pharmacists in the opportunity for generic use and generic substitution', Medical Care 40(8), $662-674$.

Pick, W., 2008, 'Foreword', in Office of the Registrar of Medical Schemes, Evaluation of medical schemes' cost increases: Findings and recommendations, pp. 7-8, Council for Medical Schemes, Pretoria.

Quick, J.D., Hogerzeil, H.V., Velásquez, G. \& Rägo, L., 2002, 'Twenty-five years of essential medicines', Bulletin of the World Health Organization 80(11), 913-914.

$S A S$ version 9.1, 2005, computer software, The SAS Institute Inc., Cary, New York.

Simoens, S., De Bruyn, K., Bogaert, M. \& Laekeman, G., 2005, 'Pharmaceutical policy regarding generic drugs in Belgium', Pharmacoeconomics 23(8), 755-766.

Snyman, J.R. (ed.), 2006, Monthly index of medical specialities, MIMS, Pretoria.

South Africa Government, 1997, Medicines and Related Substance Control Amendment Act, Government Printer, Pretoria.

Steyn, R., 2005, The usage of antidiabetic drugs: A managed care approach, M Pharm Dissertation, Department of Pharmacy Practice, North-West University.

Taylor, B., 2007, 'Rationing of medicines and health care technology', in S. Harrison., R. Bhana \& A. Ntuli (eds.), South African health review-2007, pp. 123-138, Health Systems Trust, Durban.

Tilson, L., McGowan, B., Ryan, M. \& Barry, M., 2003, 'Generic drug utilisation on the General Medical Services (GMS) Scheme in 2001', Irish Medical Journal 96(6), 176-179.

Ubeda, A., Cardo, E., Sellés, N., Broseta, R., Trillo, J.L. \& Fernández-limós, F., 2007, 'Antidepressant utilization in primary care in a Spanish region: Impact of generic and reference-based pricing policy (2000-2004)', Social Psychiatry and Psychiatric Epidemiology 42(3), 181-188.

Van der Westhuizen, E., 2007, Overview of antidepressants usage and cost 2004 until 2006, M Pharm Dissertation, Dept. of Pharmacy Practice, North-West University.

World Bank., 2009, South Africa - country brief, viewed 13 August 2009, from http:/ / www.worldbank.org

World Health Organization, 2008, World health statistics-2008, World Health Organization, Geneva. 